\title{
Contamination by parasites of zoonotic importance in fecal samples from Florianópolis Beaches, Santa Catarina State, Brazil
}

\section{Contaminação por parasitas de importância zoonótica em amostras fecais nas praias de Florianópolis, SC, Brasil}

\author{
Patrizia Ana BRICARELLO ${ }^{1}$; Ellen Antunes MAGAGNIN²; Thailini de OLIVEIRA³ ${ }^{3}$ Alice da SILVA ${ }^{3}$; \\ Lenilza Mattos LIMA ${ }^{4}$ \\ ${ }^{1}$ Universidade Federal de Santa Catarina, Centro de Ciências Agrárias, Departamento de Zootecnia e Desenvolvimento Rural, \\ Florianópolis - SC, Brazil \\ ${ }^{2}$ Universidade Federal de Santa Catarina, Curso de Graduação em Medicina Veterinária, Curitibanos - SC, Brazil \\ ${ }^{3}$ Universidade Federal de Santa Catarina, Centro de Ciências Agrárias, Curso de Graduação em Zootecnia, Florianópolis - SC, Brazil \\ ${ }^{4}$ Universidade Federal de Santa Catarina, Centro de Ciências da Saúde, Departamento de Análises Clínicas, Florianópolis - SC, Brazil
}

\begin{abstract}
Helminths and protozoa are examples of endoparasites that, during their biological cycles, can alternate between free-life stages and parasitic stages in the environment. Pets, such as dogs and cats, live together with humans and play a significant role in society; however, these animals may carry many parasites which, besides showing direct pathogenicity to the host, represent risks to human health, as is the case with parasitic zoonoses. Public areas like parks, gardens, squares, and beaches may offer risks to human users since these environments may contain feces deposited by parasitized dogs. This study verified the occurrence of helminth eggs and/or protozoan cysts or oocysts in fecal samples collected from sand strips at the beaches Armação do Pântano do Sul, Campeche and Morro das Pedras, in the south of Florianópolis Island, Santa Catarina State (SC), during the summer period. Pet feces were collected in the 2016-2017 summer season, from December 2016 to February 2017. In the Laboratory of Animal Parasitology (CCA/UFSC), fecal samples were processed based on Willis-Mollay flotation technique and Hoffman sedimentation technique. Samples from all three analyzed beaches were positive for the presence of parasites and fecal material was found along the seashore, sites where people freely walk barefoot. Of 104 fecal samples collected, 45 (43.27\%) were positive for one or more parasites. The greatest prevalence was found in Campeche Beach, which had $72.22 \%$ positive samples. Ancylostomids were most prevalent, indicating that cutaneous larva migrans is likely to occur in humans. Other parasites such as Trichuris vulpis, Toxocara spp. and Giardia spp. were also detected in coproparasitological analyses. Based on the results, it was concluded that contamination of the beaches in Florianópolis Island, SC, constitutes a public health problem due to the possibility of zoonosis transmission. These results reinforce the importance of establishing health programs for parasite control and education programs to elucidate the risks of transmission of these zoonoses to the population, in an attempt to reduce environmental contamination risks at beaches of seaside resorts.
\end{abstract}

Keywords: Zoonoses. Helminths. Domestic animals. Beaches. Public health.

\section{Resumo}

Helmintos e protozoários são exemplos de endoparasitas que, durante seus ciclos biológicos, podem alternar fases de vida livre e de vida parasitária no ambiente. Animais de companhia, como cães e gatos, possuem convívio direto com o homem e desempenham importante papel na sociedade, porém eles podem carregar muitos parasitas que, além da patogenicidade direta ao hospedeiro, representam riscos à saúde humana, como no caso das zoonoses parasitárias. A utilização de áreas públicas (como parques, jardins, praças e praias) por estes animais pode oferecer riscos aos frequentadores humanos, uma vez que pode ocorrer a deposição de fezes nesses ambientes por cães parasitados. Este estudo investigou a ocorrência de ovos de helmintos e/ou cistos ou oocistos de protozoários em amostras de fezes coletadas nas faixas de areia das praias da Armação do Pântano do Sul, Campeche e Morro das Pedras, no sul da ilha de Florianópolis, Santa Catarina, Brasil, durante o período de verão. As coletas de amostra de fezes de animais domésticos foram realizadas na temporada de verão 2016-2017, de dezembro de 2016 a fevereiro de 2017. No Laboratório de Parasitologia Animal (CCA/UFSC), as amostras de fezes foram processadas pela técnica de flutuação de Willis-Mollay e pela técnica de sedimentação de Hoffman. Amostras colhidas nas três praias analisadas mostraram-se positivas para a presença de parasitos. Material fecal foi observado ao longo de toda orla, locais em que as pessoas caminham livremente e sem calçados. De um total de 104 amostras de fezes coletadas nas praias, $45(43,27 \%)$ estavam positivas a um ou mais parasitas. A praia do Campeche foi a que apresentou maior prevalência, com $72,22 \%$ de amostras positivas. Os ancilostomídeos, responsáveis pela larva migrans cutânea em humanos, foram os mais prevalentes. Outros parasitas 
como Trichuris vulpis, Toxocara spp. e Giardia spp. também foram detectados nas análises coproparasitológicas. Com base nos resultados obtidos, concluímos que a contaminação das praias na Ilha de Florianópolis, SC, constitui um problema de saúde pública, devido à possibilidade de transmissão de zoonoses. Esses resultados reforçam a importância da implantação de programas sanitários de controle de parasitas e programas de educação que esclareçam os riscos de transmissão dessas zoonoses à população, a fim de reduzir os riscos de contaminação ambiental nas praias de balneários.

Palavras-chave:Zoonoses. Helmintos. Animais domésticos. Praias. Saúde pública.

Correspondence to:

Patrizia Ana Bricarello

Universidade Federal de Santa Catarina, Centro de Ciências

Agrárias, Departamento de Zootecnia e Desenvolvimento Rural

Rod. Admar Gonzaga, 1346, Itacorubi

CEP 88034-000, Florianópolis, SC, Brazil

e-mail: patrizia.bricarello@ufsc.br

Received: 31/05/2017

Approved: 07/11/2017

\section{Introduction}

Pets, such as dogs and cats, live together with humans and play a significant role in society, contributing to the physical, social and emotional development of children and to the well-being of their owners. However, both pet species can harbor several parasites that are potentially transmissible to humans. Special attention should be given to ascarids and ancylostomatids, which affect dogs and cats worldwide, considering their spread and risk to animal and human health (MADRID et al., 2005; MATESCO et al., 2006; TRAVERSA, 2012;DANTAS-TORRES; OTRANTO, 2014).

From an epidemiologic point of view, by having free access to recreation and leisure sites (beaches, parks, gardens and squares), pets may contaminate the soil, releasing nematodes eggs in their feces and posing risks to human users (MENTZ et al., 2004; CAPUANO; ROCHA, 2006; SANTOS et al., 2006; OLIVEIRA, 2007; SPÓSITO; VIOL, 2012; VITAL et al., 2012). These eggs remain viable in the environment for lengthy periods due to the consistency of their outer cuticle, exposing the human population to the risk of infection and disease development(NIJSSE et al., 2015).

Parasites affecting dogs and cats are widely distributed in all regions of Brazil. In Manaus, Amazonas State, endoparasite prevalence in stray dogs was $100 \%$, of which $85 \%$ was for hookworms (PEREIRA JÚNIOR; BARBOSA, 2013). In the Federal District, parasites of zoonotic potential were detected in $25 \%$ of fecal samples collected from the domiciled dogs and cats, streets and Zoonosis Control Center (VITAL et al., 2012). In Salvador, Bahia, $54 \%$ of the samples collected from beaches were contaminated with parasites, prevailing the genus Ancylostoma spp. (SANTOS et al., 2006). In Cuiabá, Mato Grosso, 50\% necropsied cats had Ancylostoma braziliense and other parasites of public health importance (RAMOS et al., 2013). In Espírito Santo, 75\% fecal samples from dogs of the Zoonosis Control Center were positive for parasitic zoonoses (ALVES et al., 2010). In Curitiba, Paraná, Ancylostoma spp., Trichuris vulpis, Toxocara spp. and Giardia spp. were present in fecal samples from dogs (LEITE et al., 2007). In the central area of the major seaside resort in the south coast of Rio Grande do Sul State, positive samples were around $71.3 \%$ for Ancylostoma spp., 32.5\% for Trichuris and 9.3\% for Toxocara spp. (SCAINI et al., 2003). In Monte Negro Municipality, Rondônia, approximately $84 \%$ of the dog samples were positive, especially for Ancylostoma spp., Toxocara canis and Sarcocystis spp. (LABRUNA et al., 2006). Nevertheless, some authors have emphasized that few studies in the literature address this issue related to beaches (BLAZIUS et al., 2006; MATESCO et al., 2006; SANTOS et al., 2006).

Beach sand presents the epidemiological factors necessary for the occurrence of parasitic diseases transmitted by animals: weather conditions favorable to free-living stages of parasites and many stray dogs walking freely on the beach promenade and sand, resulting in waste accumulation (LEITE et al., 2006; MATESCO et al., 2006). Studies conducted in Brazil and other countries have found Ancylostoma spp., Toxocara spp., Giardia spp., and Trichuris spp. as the major canine parasites of zoonotic importance (LEITE et al., 2006; LITTLE et al., 2009; OVERGAAUW et al., 2009; ALVES et al., 2010; CHEN et al., 2012; MARIANI et al., 2014; ROMERO et al., 2015; VILLANUEVEetal., 2015).

Ancylostoma spp. is the etiologic agent of cutaneous larva migrans syndrome in humans, which is caused when infective larvae of the nematode penetrate the skin of humans and migrate through the subcutaneous tissue, leading to linear and tortuous skin eruption (NUNES et al., 2000). A. braziliense is most often implicated in dermatological lesions, and $A$. caninum has been associated with eosinophilic enteritis and suggested as a possible cause of diffuse unilateral sub-acute neuroretinitis in humans. Other manifestations include eosinophilic pneumonitis, localized myositis, folliculitis, erythema multiforme, or ophthalmological manifestations (BOWMAN et al., 2010). 
Toxocara spp.is the etiologic agent of visceral larva migrans syndrome because of the migration of helminth larvae, especially T. canis, through organs like lungs, brain, eyes and liver (RUBINSKY-ELEFANT; FERREIRA, 2012). Trichuris vulpis can cause anemia and diarrhea in dogs and the lesions left by this parasite may lead to secondary bacterial infections (VASCONCELLOS et al., 2006). For humans, Sakano et al. (1980) and Mirdha et al. (1998) reported occurrence of visceral larva migrans caused by T. vulpis, besides ulcers and intestinal infections caused by the adult parasite.

Giardia spp. may have varied pathogenicity degrees. This zoonotic protozoan leads to severe disease in puppies and animals that are debilitated or present concomitant diseases, of which diarrhea is most common (MUNDIM et al., 2003). Clinical manifestations of giardiasis in humans include fatty stools, flatulence, diarrhea and abdominal cramps, although most cases are asymptomatic (ELBAKRI et al., 2014). Some studies have found moderate frequency of cysts of Giardia spp. in fecal samples from domestic animals in different regions of Brazil (SILVA; ARAÚJO, 2013; MOTA et al., 2014).

Florianópolis is one of the main tourist destinations of the country with more than 100 beaches and receives visitors from several parts of the world during vacation periods, when its population of 421,240 inhabitants doubles (IBGE, 2011) The complementary law no. 94 , in force since December 18 ,
2001, in Florianópolis, aims to control and protect animal populations, as well as prevent zoonotic diseases, and the Municipal Secretariat of Health is responsible for its execution. According to Article 8 of this law, presence of dogs, cats or other animals is prohibited at beaches (FLORIANÓPOLIS, 2001). However, at several beaches in the south of Florianópolis Island, many free-roaming dogs are seen, frequently without any handler, and a great quantity of excreta can be easily found on the sand strip.

Considering the lack of information and research about the contamination degree of beaches in the south of Florianópolis Island, this study aimed to verify the prevalence of helminth eggs and/or protozoan cysts and oocysts in fecal samples collected from the sand strip of three beaches located in the South region of Florianópolis Island, Santa Catarina (SC).

\section{Materials and Methods}

During the study period, 104 fecal samples were analyzed. Collections were made at the beaches of Armação do Pântano do Sul, Campeche and Morro das Pedras, located in the south of Florianópolis Island, SC, Brazil (Figure 1). The extent of beaches Campeche and Morro das Pedras totals 7,500 $\mathrm{m}$ since there is no physical barrier dividing these beaches. As to Armação do Pântano do Sul, its extent is approximately $2,500 \mathrm{~m}$, totaling $10,000 \mathrm{~m}$ of sampled area.

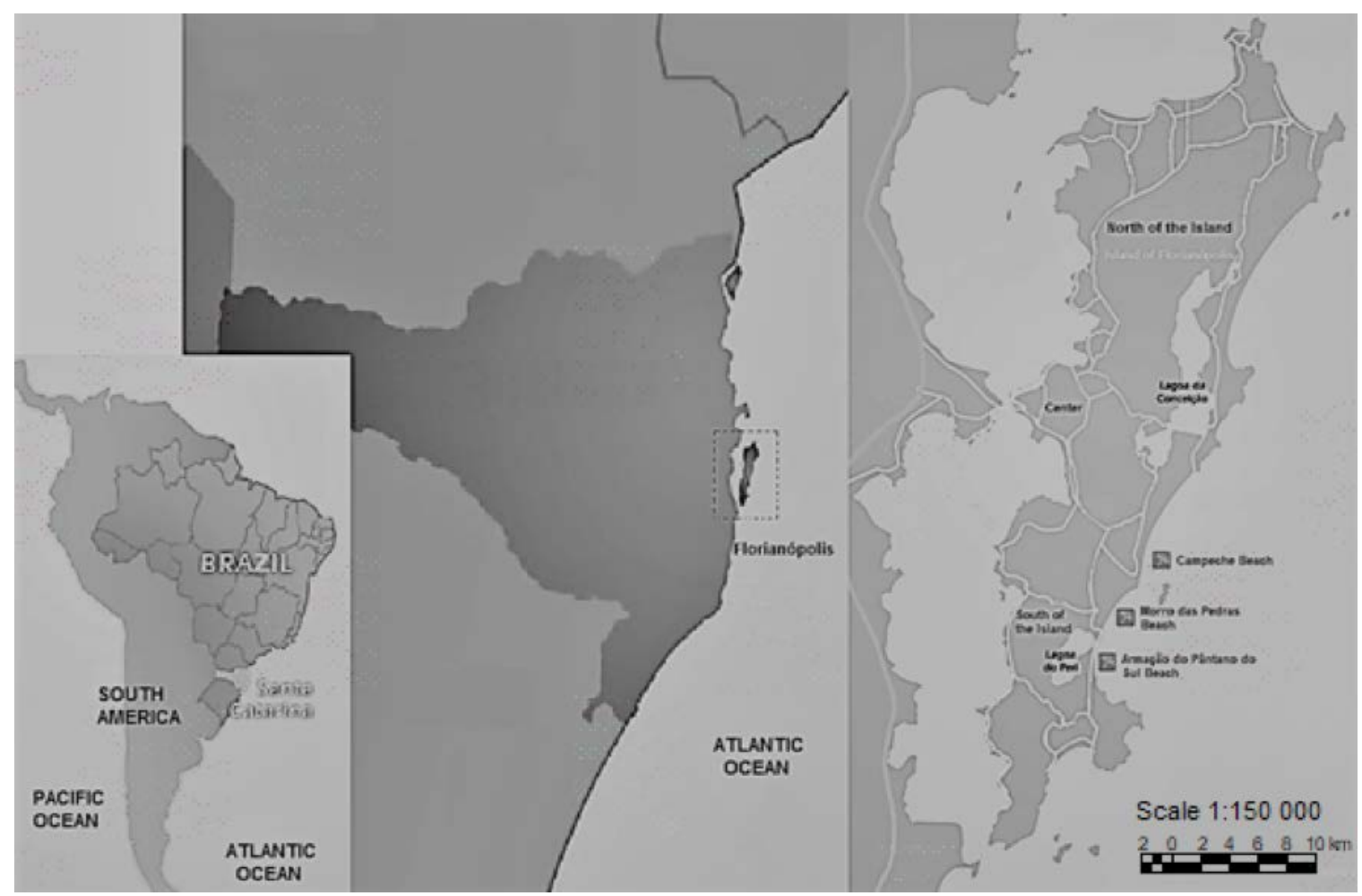

Figure 1 - Geographic location of the municipality of Florianópolis, Santa Catarina State, Brazil, and the beaches of the present study

Source: Adapted from Brasil - Nossa marca é a diversidade (2010), Florianópolis - Mapa da Ilha de Santa Catarina (2010) e Santa Catarina - um “Estado" de felicidade (2010) 


\section{Sampling}

To evaluate the prevalence of parasites contamination at the beaches during the 2016-2017 summer season, fecal samples were collected from December 2016 to February 2017, early in the morning, from the beach sand itself, as well as from all nearby areas such as piers, promenades and sidewalks that give access to the beach.

Fecal samples were stored in individual plastic bags that were labeled (sample number and collection date and site) and placed inside Styrofoam boxes containing recyclable ice for transportation to the laboratory where tests were conducted. Samples were transferred to wellsealed plastic containers, added with preservative SAF (sodium acetate, acetic acid, formaldehyde and distilled water) and kept under refrigeration. Analyses were carried out at the Laboratory of Animal Parasitology, Department of Animal Science and Rural Development, Center for Agrarian Sciences, Federal University of Santa Catarina (UFSC) in Florianópolis, SC, Brazil.

Early morning collections were prioritized to prevent sun-dried samples. To standardize the physical characteristics of feces, preventing excessively dried samples, a photographic record was obtained of fresh feces, slightly dried feces and moderately dried feces, and these photos were subsequently used to classify the remaining collected samples.

\section{Parasitological techniques}

Two distinct techniques were used to analyze fecal samples: Willis-Mollay flotation technique (MONTEIRO, 2011) and simple sedimentation technique, known as Hoffmann technique (HOFFMANN, 1987). For Willis-Mollay technique, samples received Lugol stain to make Giardia spp. Identification easier. Whenever necessary, morphometry of parasitic structures was employed for identification.

Analyzing similar studies, we noticed there is no recurrent pattern to determine the number of samples necessary to estimate the population proportion.

According to Mourão Júnior (2009), determining the sample size $n$ is a dynamic process which may change as data are collected and analyzed. One thing is sure: if the $n$ is sufficient to ensure that the sample represents the population, such $n$ is adequate. For fecal samples, we adopted convenience sampling, i.e., using the available elements or data (MOURÃO JÚNIOR, 2009).

\section{Results}

All three analyzed beaches, Armação do Pântano do Sul, Campeche and Morro das Pedras, had positive samples for presence of canine parasites, and fecal material was found along the beach shore, at sites of access to the beach and at sites where people freely walk barefoot (Table 1). Of 104 fecal samples collected, 45 (43.27\%) were contaminated.

Table 1 - Helminth eggs and protozoan cysts in fecal samples collected from beaches in the south of Florianópolis Island, Santa Catarina State, in the 2016/2017 summer season

\begin{tabular}{ccccccc}
\hline Beaches & Total of samples & Positive samples & Hookworms & Giardia & Toxocara & Trichuris \\
\hline $\begin{array}{c}\text { Armação do } \\
\text { Pântano do Sul }\end{array}$ & 51 & 15 & 13 & 0 & 0 & 3 \\
Campeche & 18 & 13 & 12 & 2 & 1 & 3 \\
Morro das Pedras & 35 & 17 & 14 & 1 & 0 & 7 \\
Total & 104 & 45 & 39 & 3 & 1 & 13 \\
Prevalence & - & $43.27 \%$ & $37.5 \%$ & $2.88 \%$ & $0.96 \%$ & $12.5 \%$ \\
\hline
\end{tabular}

The analyzed beaches had highly different results. Campeche showed the greatest prevalence, with 72.22\% positive samples. Morro das Pedras ranked second with a prevalence value of 48.57\%, and Armação do Pântano do Sul ranked third with prevalence of $29.41 \%$.

\section{Discussion}

According to the global prevalence of intestinal helminths and protozoa found in our study (43.27\%), infection level was high, if compared to other studies conducted at Brazilian beaches (CASTRO et al., 2005; 
SANTOS et al., 2006), but apparently lower, if compared to the prevalence superior to $60 \%$ found in other parts of Brazil for beaches, areas close to beaches or central areas of cities (BLAZIUS et al., 2006; LABRUNA et al., 2006; ALVES et al., 2010; PEREIRA JÚNIOR; BARBOSA, 2013).

Hookworms were most prevalent, which indicates possible high risk of people acquiring cutaneous larva migrans at beaches. Despite the methodological differences among parasitological surveys carried out in Brazil, Ancylostoma has consistently been reported as the most frequent helminth genus in Brazilian dogs, as shown by Coronato et al. (2012), in Ilha de Marambaia, Rio de Janeiro State, where 91.9\% samples were parasitized. In a study carried out in Cuiabá, A. braziliense was the most prevalent helminth in necropsies of cats from the Zoonosis Center (RAMOS et al., 2013). This helminth also showed high prevalence in a study performed in Rondônia (73.7\%), which evidenced great environmental contamination by this parasite in urban areas (LABRUNA et al., 2006).

In the present study, prevalence of eggs of Toxocara spp. $(0.96 \%)$ was like that reported by Matesco et al. (2006) in a study conducted at Ipanema Beach in Porto Alegre, RS, where prevalence of eggs was low for Toxocara spp. (0.8\%) and high for Ancylostoma spp. (29.8\%). According to Matesco et al. (2006), these results indicate that the risk of infection by cutaneous larva migrans is higher than that by visceral larva migrans. However, these results may be underestimated as adult dogs may develop resistance and the highest parasite burdens and prevalence of patent Toxocara infections are observed in puppies of dogs and cats less than six months of age (DEPLAZES et al., 2011). In different regions of Brazil, numerous cases of visceral and cutaneous larva migrans have been described for humans (MUSSO et al., 2007; SCHUSTER et al., 2013), and serological data have confirmed elevated level of exposure of humans to Toxocara spp. (FRAGOSO et al., 2011; SOUZA et al., 2011; MATTIA et al., 2012; MENDONÇA et al., 2012; SCHOENARDIE et al., 2013).

Trichuris vulpis has a direct life cycle, and humans become infected by having contact with embryonated eggs present on the soil contaminated by dogfeces (DICESAREetal.,2012). This parasite of zoonoticimportance was the second most prevalent parasite and was present in $11.54 \%$ contaminated samples. This finding is like that obtained by Leite etal. (2006), in Itapema, SC, where $13.9 \%$ of the stray dogs analyzed were contaminated by this parasite. In another study also conducted on the coast ofSC, in Meia-Praia, Itapema, only 2\% of the collected samples were contaminated by Trichuris (BLAZIUS etal., 2006).
Strains of Giardia spp. found in fecal samples from dogs are potentially infective to humans and may cause giardiasis. Thus, Giardia cysts released in the feces represent an important source of contamination to humans and other animals (SILVA; ARAÚJO, 2013). Although the prevalence found in this study was apparently low, Giardia transmission from animal to human represents an imminent risk of zoonotic transmission due to the domestic behavior of dogs and cats with their owners (MOTA et al., 2014)

Recent studies on beach contamination by zoonotic parasites along the extensive coast of Brazil are scarce, which leads to certain negligence in infections by these agents. Florianópolis City Hall is aware of the cases of cutaneous larva migrans among the human population and has provided, through its Zoonosis Control Center, an informative booklet (FLORIANÓPOLIS, 2014). This document emphasizes the importance of pets not staying on the beach, owners collecting and correctly discarding dog feces, as well as implementing health and environmental educational measures to the population. In Mexico City, control and prevention programs were established by means of deworming campaigns and health education to prevent fecal contamination in the soil, water and food, encouraging responsible pet ownership. A study on the recent situation of the city showed that the endoparasite prevalence rates for the collected fecal samples reduced (13\%) but remain a potential risk factor for humans (ROMERO et al., 2015).

Although the presence of stray dogs or dogs followed by their owners on the beach is not permitted by law, it was noticed at all studied beaches during sample collection. It must be emphasized that in all beaches there were signs prohibiting the presence of dogs on the beach; however, no type of inspection by agents of the City Hall or environmental organs was ever observed during the study period. Either stray dogs or dogs with their owners or handlers but without a leash had free access to leisure sites shared by children and adults, frequently defecating there. The beaches of Campeche and Morro das Pedras had marked presence of stray dogs, which are often fed by the population in the village and market close to the beaches, but the physical aspect of such dogs suggests neglected general health. A study carried out in the southeast of Brazil revealed that most dog owners do not know the intestinal parasite species of dogs, transmission mechanisms, risk factors of zoonotic infections or specific prophylactic measures (KATAGIRI; OLIVEIRA-SIQUEIRA, 2008). 
On the other hand, some countries allow dogs access to beaches, imposing only some rules for public safety and health, as is the case of Guernsey, an island located in the English Channel, northwest of France. Guernsey's current legislation for dog control at the beaches dates from 1992 and aims to define the owners' responsibility for the society; owners must remove any feces deposited by their dogs, keep their dogs under control and respect the prohibition period (STATES OF GUERNSEY, 2011).

The zoonosis control program must include mandatory collection of feces and appropriate garbage cans available for waste disposal, along with environmental monitoring. An example of advance in public politics for the control of zoonosis transmitted by pets can be seen at the beaches of California, USA, which are managed by public entities and have the presence of dogs officially prohibited in most of the 1,100 kilometers along the coast of the state. However, in other 60 beaches, the presence of dogs is legally allowed, and the owners have total responsibility. The legislation on collection of pet feces at the beaches emphasizes the risk of environmental and water contamination, and several types of garbage cans specific for waste disposal are available. Water and environmental quality is monitored from a sanitary point of view (FOSTER, 2006).

Veterinarians and health professionals play an important role in disseminating information about the forms of parasite transmission and zoonosis prevention. According to Pereira et al. (2016), only 35.2\% interviewed owners did not know about parasitic zoonoses. The owners' increased awareness of parasitic zoonoses must be added to control measures to reduce the risks of infections in pets and humans, which should be implemented by veterinarians, using diverse resources such as informative

\section{References}

AlveS, D. P.; CARNEIRO, M. B.; DIAS, J. D. C.; MARTINS, I. V. F. Ocorrência de parasitos de cães recolhidos pelo centro de controle de zoonoses de Cachoeiro de Itapemirim, estado do Espírito Santo. Revista Brasileira de Medicina Veterinária, v. 32, n. 2, p. 97-100, 2010.

BLAZIUS, R. D.; SILVA, O. S.; KAULING, A. L.; RODRIGUES, D. F. P; LIMA, M. C. Contaminação da areia do Balneário de Laguna, SC, por Ancylostoma spp, e Toxocara spp. em amostras fecais de cães e gatos. Arquivos Catarinenses de Medicina, v. 35, n. 3, p. 55-58, 2006. booklets, news bulletins in social networks and short lectures. Free veterinary care to low-income owners must be considered and promoted by governmental entities, such as deworming programs for all the pet population with the aim of intensifying urgent public health measures.

National guidelines to control endoparasites of dogs and cats need foundation, such as those existing in United States (CDCP, 2004), Canada (CPEP, 2009) and Europe (ESCCAP, 2017). Such guidelines are essential to ensure that veterinarians have access to the most recent information about control of dog and cat parasites.

\section{Conclusion}

Based on the obtained results, we concluded that contamination of the studied beaches in Florianópolis, SC constitutes a public health problem since zoonotic agents are present. These results reinforce the importance of establishing health programs to control parasites and education programs to elucidate the risks of zoonosis transmission to the population, with the aim of reducing the risks of environmental contamination at seaside resorts. Effective inspection must be considered to enforce the law that prohibits access of dogs and cats to beaches, considering both stray animals and pets with their owners. In addition, public politics to regulate the stay pets in certain areas such as beaches and parks must be discussed with the population so that the pertinence of this measure can be debated, which already occurs in other countries. The benefits of leisure activities shared between humans and pets are relevant, but public health aspects must be prioritized.

BOWMAN, D. D.; MONTGOMERY, S. P.; ZAJAC, A. M.; EBERHARD, M. L.; KAZACOS, K. R. Hookworms of dogs and cats as agents of cutaneous larva migrans. Trends in Parasitology, v. 26, n. 4, p. 162-167, 2010. doi: 10.1016/j.pt.2010.01.005.

BRASIL - Nossa marca é a diversidade. Litoral de Santa Catarina.com, Florianópolis, 2010. Available from: $<$ https://goo.gl/h3fvCo $>$. Viewed: 12 Aug. 2017.

CANADIAN PARASITOLOGY EXPERT PANEL (CPEP). Canadian guidelines for the treatment of parasites in 
dogs and cats. [S.1.]: CPEP, 2009. 32 p. Available from: <https://goo.gl/pkPw2x>. Viewed: 4 Aug. 2017.

CAPUANO, D. M.; ROCHA, G. M. Ocorrência de parasitas com potencial zoonótico em fezes de cães coletadas em áreas públicas do município de Ribeirão Preto, SP, Brasil. Revista Brasileira de Epidemiologia, v. 9, n. 1, p. 81-86, 2006. doi: 10.1590/S1415-790X2006000100010.

CASTRO, J. M.; SANTOS, S. V.; MONTEIRO, N. A. Contaminação de canteiros da orla marítima do município de Praia Grande, São Paulo, por ovos de Ancylostoma e Toxocara em fezes de cães. Revista Sociedade Brasileira Medicina Tropical, v. 38, n. 2, p. 199-201, 2005. doi: 10.1590/S0037-86822005000200017.

CENTERS FOR DISEASE CONTROL AND PREVENTION (CDCP). Guidelines for veterinarians: prevention of zoonotic transmission of ascarids and hookworms of dogs and cats. [S.1.]: CDC, 2004. 12 p. Available from: <https://goo.gl/Md98oQ>. Viewed: 2 Aug. 2017.

CHEN, J.; XU, M.-J.; ZHOU, D.-H.; SONG, H.-Q.; WANG, C.-R.; ZHU, X. Q. Canine and feline parasitic zoonoses in China. Parasites \& Vectors, v. 5, n. 1, p. 152, 2012. doi: 10.1186/1756-3305-5-152.

CORONATO, B.; BASTOS, O. M. P.; DUARTE, R.; DUARTE, A. N.; LAURENTINO-SILVA, V.; SOUZA, M. B.; UCHÔA, C. M. A. Parasites in stool samples in the environment of Ilha da Marambaia, Rio de Janeiro, Brazil: an approach in public health. Revista do Instituto de Medicina Tropical de São Paulo, v. 54, n. 2, p. 65-68, 2012. doi: $10.1590 /$ S0036-46652012000200002.

DANTAS-TORRES, F.; OTRANTO, D. Dogs, cats, parasites, and humans in Brazil: opening the black box. Parasites \& Vectors, v. 7, p. 1-25, 2014. doi: 10.1186/1756-3305-7-22.

DEPLAZES, P.; VAN KAPEN, F.; SCHWEIGER, A.; OVERGAAUW, P. A. M. Role of pet dogs and cats in the transmission of helminth zoonoses in Europe, with a focus on echincoccosis and toxocarosis. Veterinary Parasitology, v. 182, n. 1, p. 41-53, 2011. doi: 10.1016/j.vetpar.2011.07.014.
DI CESARE, A.; CASTAGNA, G.; MELONI, S.; OTRANTO, D.; TRAVERSA, D. Mixed trichuroid infestation in a dog from Italy. Parasites \& Vectors, v. 5, p. 1-6, 2012. doi: 10.1186/1756-3305-5-128.

ELBAKRI, A.; SAMIE, A.; BESSONG, P.; POTGIETER, N.; ODEH, R. A. Detection and molecular characterisation of Giardia lamblia genotypes in Sharjah, United Arab Emirates. Transaction Royal Society Tropical Medicine Hygiene, v. 108, n. 8, p. 466-473, 2014. doi: 10.1093/trstmh/tru083.

EUROPEAN SCIENTIFIC COUNSEL COMPANION ANIMAL PARASITES (ESCCAP). Worm control in dogs and cats. Malvern: ESCCAP, 2017. 39 p. (Guideline 1., 3. ed.). Available from: <https://goo.gl/tiAQhz>. Viewed: 19 Aug. 2017.

FLORIANÓPOLIS - Mapa da Ilha de Santa Catarina. Litoral de Santa Catarina.com, Florianópolis, 2010. Available from: <https://goo.gl/S1AKiS >. Viewed: 12 Aug. 2017.

FLORIANÓPOLIS. Prefeitura. Lei complementar no 94 , de 18 de dezembro de 2001. Dispõe sobre o controle e proteção de populações animais, bem como a prevenção de zoonoses, no município de Florianópolis, e dá outras providências. Leis Municipais, [S.1.], 2001. Available from: <https://goo.gl/9LLa8t>. Viewed: 3 Mar. 2017.

FLORIANÓPOLIS. Secretaria Municipal de Saúde. Centro de Controle de Zoonoses. Larva Migrans Cutânea. Florianópolis, 2014. Available from: <https://goo.gl/bfiijo $>$. Viewed: 28 Jun. 2016.

FOSTER, L. K. Dogs on the beach: a review of regulations and issues affecting dog beaches in California. Sacramento: California Research Bureau, 2006. 69 p. Available from: <https://goo.gl/MpKhxh>. Viewed: 2 Mar. 2017.

FRAGOSO, R. P.; MONTEIRO, M. B. M.; LEMOS, E. M.; PEREIRA, F. E. L. Anti-Toxocara antibodies detected in children attending elementary school in Vitória, State of Espírito Santo, Brazil: prevalence and associated factors. Revista Sociedade Brasileira Medicina Tropical, v. 44, n. 4, p. 461-466, 2011. doi: 10.1590/S0037-86822011000400012. 
HOFFMANN, R. P. Diagnóstico de parasitismo veterinário. Porto Alegre: Sulina, 1987. 156 p.

INSTITUTO BRASILEIRO DE GEOGRAFIA E ESTATÍsTICA (IBGE). Censo demográfico 2010: características da população e dos domicílios: resultados do universo. Rio de Janeiro: IBGE, 2011. 270 p. Available from: $<$ https://goo.gl/QD5FvA>. Viewed: 15 Dec. 2016.

KATAGIRI, S.; OLIVEIRA-SIQUEIRA, T. C. Prevalence of dog intestinal parasites and risk perception of zoonotic infection by dog owners in São Paulo State, Brazil. Zoonoses Public Health, v. 55, n. 8-10, p. 406-413, 2008. doi: 10.1111/j.1863-2378.2008.01163.x.

LABRUNA, M. B.; PENA, H. F. J.; SOUZA, S. L. P; PINTER, A.; SILVA, J. C. R.; RAGOZO, A. M. A.; CAMARGO, L. M. A.; GENNARI, S. M. Prevalência de endoparasitas em cães da área urbana do município de Monte Negro, Rondônia. Arquivos do Instituto Biológico, v. 73, n. 2, p. 183-193, 2006.

LEITE, L. C.; BANDEIRA, C. R.; CÍRIO, S. M; LUZ, E; LEITE, S. C.; LUNELLI, D.; WEBER, S.; COELLI, C. R. V. R. Ocorrência de ovos de Ancylostoma spp. e Trichuris spp. em fezes de cães em meia-praia, Itapema, Santa Catarina, Brasil. Estudos de Biologia, v. 28, n. 65, p. 105-110, 2006.

LEITE, L. C.; CÍRIO, S. M; NAVARRO-SILVA, M. A.; ZADOROSNEI, A. C. B.; LUZ, E; MARINONI, L. P.; LEITE, S. C.; LUNELLI, D. Ocorrência de endoparasitas em amostras de fezes de cães (Canis familiaris) da Região Metropolitana de Curitiba, Paraná, Brasil. Revista Estudos de Biologia, v. 29, n. 68-69, p. 319-326, 2007.

LITTLE, S. E.; JOHNSON, M. E.; LEWIS, D.; JAKLITSCH, R. P.; PAYTON, M. E.; BLAGBURN, B. L.; BLOWMAN, D. D.; MOROFF, S.; TAMS, T.; RICH, L.; AUCOIN, D. Prevalence of intestinal parasites in pet dogs in the United States.VeterinaryParasitology,v.166,n.1-2,p.144-152,2009. doi: 10.1016/j.vetpar.2009.07.044.

MARIANI, R.; TOMAZZONI, F. V.; RODRIGUES, A. D. Prevalência de parasitas intestinais em cães de um abrigo de animais no sul do Brasil. Ciência em Movimento, v. 16, n. 33, p. 85-92, 2014. doi: 10.15602/1983-9480/cmbs.v16n33p85-92.
MATESCO, V.C.; MENTZ, M. B.; ROTT, M. B.; SILVEIRA, C. O. Contaminação sazonal por ovos de helmintos na praia de Ipanema, em Porto Alegre, Rio Grande do Sul, Brasil. Revista Agropecuária Tropical, v. 35, n. 2, p. 135-141, 2006. doi: 10.5216/rpt.v35i2.1902.

MATTIA, S.; COLLI, C. M.; ADAMI, C. M.; GUILHERME, G. F.; NISHI, L.; RUBINSKY-ELEFANT, G.; MARCHIORO, A. A.; GOMES, M. L.; FALAVIGNA-GUILHERME, A. L. Seroprevalence of Toxocara infection in children and environmental contamination of urban areas in Paraná State, Brazil. Journal of Helminthology, v. 86, n. 4, p. 440-445, 2012. doi: 10.1017/S0022149X11000666

MENDONÇA, L. R.; VEIGA, R. V.; DATTOLI, V. C. C.; FIGUEIREDO, C. A.; FIACCONE, R.; SANTOS, J.; CRUZ, Á. A.; RODRIGUES, L. C.; COOPER, P. J.; PONTES-DECARVALHO, L. C.; BARRETO, M. L.; ALCANTARANEVES, N. M. Toxocara seropositivity, atopy and wheezing in children living in poor neighbourhoods in urban Latin American. Plos Neglected Tropical Diseases, v. 6, n. 11, p. 1886, 2012. doi: 0.1371/journal.pntd.0001886.

MENTZ, M. B.; ROTT, M. B.; JACOBSEN, S. I. V.; BALDO, G.; RODRIGUES-JÚNIOR, V. Frequência de ovos de Toxocara spp. Em três parques públicos da cidade de Porto Alegre, Rio Grande do Sul, Brasil. Revista de Patologia Tropical, v. 33, n. 1, p. 105-112, 2004. doi: 10.5216/rpt.v33i1.3249.

MIRDHA, B. R.; SINGH, I. G.; SAMANTRAY, J. C.; MISHRA, B. Trichuris vulpis infection in slum children. Indian Journal Gastroenterology, v. 17, n. 4, p. 154, 1998.

MONTEIRO, S. G. Parasitologia na medicina veterinária. São Paulo: Roca, 2011. 370 p.

MOTA, K. C. P.; GÓMEZ-HERNÁNDEZ, C.; REZENDEOLIVEIRA, K. Frequência de enteroparasitos em amostras de fezes de cães em um município do Pontal do Triângulo Mineiro, Minas Gerais, Brasil. Revista de Patologia Tropical, v. 43, n. 2, p. 219-227, 2014. doi: 10.5216/rpt.v43i2.31124.

MOURÃO JÚNIOR, C. A. Questões em bioestatística: o tamanho da amostra. Revista Interdisciplinar de Estudos Experimentais, v. 1, n. 1, p. 26-28, 2009. 
MUNDIM, M. J. S.; SOUZA, S. Z;; HORTÊNCIO, S. M.; CURY, M. C. Frequência de Giardia spp. por duas técnicas de diagnóstico em fezes de cães. Arquivo Brasileiro de Medicina VeterináriaeZootecnia,v.55,n.6,p.770-773,2003. doi: 10.1590/S0102-09352003000600016.

MUSSO, C.; CASTElO, J. S.; TSANACliS, A. M.; PEREIRA, F. E. Prevalence of Toxocarainduced liver granulomas, detected by immunohistochemistry, in a series of autopsies at a Children's Reference Hospital in Vitoria, ES, Brazil. Virchows Arch, v. 450, n. 4, p. 411-417, 2007. doi: 10.1007/s00428-007-0388-5.

NIJSSE, R.; MUGHINI-GRAS, L.; WAGENAAR, J. A.; FRANSSEN, F.; PLOEGER, H. W. Environmental contamination with Toxocara eggs: a quantitative approach to estimate the relative contributions of dogs, cats and foxes, and to assess the efficacy of advised interventionsindogs.Parasites\&Vectors, v.8, p. 1-13,2015. doi: 10.1186/s13071-015-1009-9.

NUNES, C. M.; PENA, F. C.; NEGRELLI, G. B.; ANJO, C. G. S.; NAKANO, M. M.; STOBBE, N. S. Ocorrência de larva migrans na areia de áreas de lazer das escolas municipais de ensino infantil, Araçatuba, SP, Brasil. Revista de Saúde Pública, v. 34, n. 6, p. 656-658, 2000. doi: 10.1590/S0034-89102000000600015.

OLIVEIRA, C. B.; SILVA, A. S.; MONTEIRO, S. G. Ocorrência de parasitas em solos de praças infantis nas creches municipais de Santa Maria, RS, Brasil. Revista da FZVA, v. 14, n. 1, 2007.

OVERGAAUW, P. A. M.; VAN ZUTPHEN, L.; HOEK, D.; YAYA, F. O.; ROELFSEMA, J.; PINELLI, E.; KNAPEN, F. V.; KORTBEEK, L. M. Zoonotic parasites in fecal samples and fur from dogs and cats in The Netherlands. Veterinary Parasitology, v. 163, n. 1-2, p. 115-122, 2009. doi: 10.1016/j.vetpar.2009.03.044.

PEREIRA, A.; MARTINS A.; BRANCAL, H.; VILHENA, H.; SILVA, P.; PIMENTA, P.; DIZ-LOPES, D.; NEVES, N.; COIMBRA, M.; ALVES, A. C.; CARDOSO, L.; MAIA, C. Parasitic zoonoses associated with dogs and cats: a survey of Portuguese pet owners' awareness and deworming practices. Parasites \& Vectors, v. 9, p. 1-9, 2016. doi: 10.1186/s13071-016-1533-2.

PEREIRA JÚNIOR, G.; BARBOSA, P. S. Prevalência de endoparasitas em cães errantes na cidade de Manaus-AM. Acta Biomedica Brasiliensia, v. 4, n. 2, 2013.

RAMOS, D. G. S.; SCHEREMETA, R. G. A. C.; OLIVEIRA, A. C. S.; SINKOC, A. L.; PACHECO, R. C. Surveyofhelminth parasites of cats from the metropolitan area of Cuiabá, Mato Grosso, Brazil. Revista Brasileira de Parasitologia Veterinária, v. 22, n. 2, p. 201-206, 2013. doi: 10.1590/S1984-29612013000200040.

ROMERO, C.; MENDOZA, G. E.; PINEDA, M. A.; NAVAS, N.; BAUTISTA, L.; HEREDIA, R. Prevalence of intestinal parasites with zoonotic potential in canids in Mexico City. Acta ScientiaeVeterinariae, v. 43, p. 1-6, 2015.

RUBINSKY-ELEFANT, G. R.; FERREIRA, M. U. Larva migrans Visceral e Cutânea. In: FERREIRA, M. U. Parasitologia Contemporânea. Rio de Janeiro: Guanabara Koogan, 2012. p. 121-127.

SAKANO, T.; HAMAMOTO, K.; KOBAYASHI, Y.; SAKATA, Y.; TSUJI, M.; USUI, T. Visceral larva migrans caused by Trichuris vulpis. Archives of Disease in Childhood, v. 55, n. 8 p. $631-633,1980$. doi: $10.1136 /$ adc. 55.8 .631 .

SANTA CATARINA - Um "Estado" de felicidade. Litoral de Santa Catarina.com, Florianópolis, 2010. Available from: <https://goo.gl/Tq78nk>. Viewed: 12 Aug. 2017.

SANTOS, N. M.; SILVA, V. M. G.; THÉ, T. S.; SANTOS, A. B.; SOUZA, T. P. Contaminação das praias por parasitos caninos de importância zoonótica na orla da parte alta da cidade de Salvador-BA. Revista de Ciências Médicas e Biológicas, v. 5, n. 1, p. 40-47, 2006. doi: 10.9771/cmbio.v5i1.4579.

SCAINI, C. J.; TOLEDO, R. N.; LOVATEL, R.; DIONELLO, M. A.; GATTI, F. A.; SUSIN, L.; SIGNORINI, V. R. M. Contaminação ambiental por ovos e larvas de helmintos em fezes de cães na área central do Balneário Cassino, Rio Grande do Sul. Revista Sociedade Brasileira de Medicina Tropical, v. 36, n. 5, p. 617-619, 2003. doi: 10.1590/S0037-86822003000500013. 
SCHOENARDIE, E. R.; SCAINI, C. J.; BROD, C. S.; PEPE, M. S.; VILLELA, M. M.; MCBRIDE, A. J.; BORSUK, S.; BERNE, M. E. Seroprevalence of Toxocara infection in children from southern Brazil. Journal of Parasitology, v. 99, n. 3, p. 537-539, 2013. doi: 10.1645/GE-3182.

SCHUSTER, A.; LESSHAFFT, H.; REICHERT, F.; TALHARI, S.; OLIVEIRA, S. G.; IGNATIUS, R.; FELDMEIER, H. Hookworm-related cutaneous larva migrans in northern Brazil: resolution of clinical pathology after a single dose of ivermectin. Clinical Infectious Diseases, v. 57, n. 8, p. 1155-1157, 2013. doi: 10.1093/cid/ cit440.

SILVA, S. M. D.; ARAÚJO, F. A. Prevalência da infecção por Giardiasp.em cãesdo município dePorto Alegre-RS, comparação entre duas populações: cães de rua e cães com proprietário provenientes de áreas de vulnerabilidade social. Journal of the Health Sciences Institute, v. 31, n. 1, p. 99-103, 2013.

SOUZA, R. F.; DATTOLI, V. C.; MENDONÇA, L. R.; JESUS, J. R.; BAQUEIRO, T.; SANTANA, C. C.; SANTOS, N. M.; BARROUIN-MELO, S. M.; ALCANTARA-NEVES, N. M. Prevalência e fatores de risco da infecção humana por Toxocara canis em Salvador, Estado da Bahia. Revista da Sociedade Brasileira de Medicina Tropical, v. 44, n. 4 , p. 516-519, 2011. doi: 10.1590/S0037-86822011000400024.

SPÓSITO, J. D.; VIOL, B. M. Avaliação da contaminação ambiental por parasitas potenciais causadores de zoonoses em espaços públicos de lazer em Apucarana, Paraná, Brasil. Revista Saúde e Pesquisa, v. 5, n. 2, p. 332-337, 2012.

STATES OF GUERNSEY. Environment Department. Legislation in relation to beaches and the coastline. Gov.gg, Saint Peter Port, 2011. Available from: $<$ https://goo.gl/RSD5yq>. Viewed: 2 Mar. 2017.

TRAVERSA, D. Pet roundworms and hookworms: a continuing need for global warming. Parasites \& Vectors, v. 5, p. 1-19, 2012. doi: 10.1186/1756-3305-5-91.

VASCONCELLOS, M. C.; BARROS, J. S. L.; OLIVEIRA, C. S. Parasitas gastrointestinais em cães institucionalizados no Rio de Janeiro, RJ. Revista de Saúde Pública, v. 40, n. 2, p. 321-323, 2006. doi: 10.1590/S0034-89102006000200020.

VILLENEUVE, A.; POLLEY, L.; JENKINS, E.; SCHURER, J.; GILLEARD, J.; KUTZ, S.; CONBOY, G.; BENOIT, D.; SEEWALD, W.; GAGNÉ, F. Parasite prevalence in fecal samples from shelter dogs and cats across the Canadian provinces. Parasites \& Vectors, v. 8, p. 1-10, 2015. doi: 10.1186/s13071-015-0870-x.

VITAL, T. E.; BARBOSA, M. R. A.; ALVES, D. S. M. M. Ocorrênciade parasitos com potencialzoonótico em fezes de cães e gatos do Distrito Federal. Ensaios e Ciência: Ciência Biológica, Agrárias e da Saúde, v. 16, n. 1, p. 9-23, 2012. doi: 10.17921/1415-6938.2012v16n1p\%25p. 